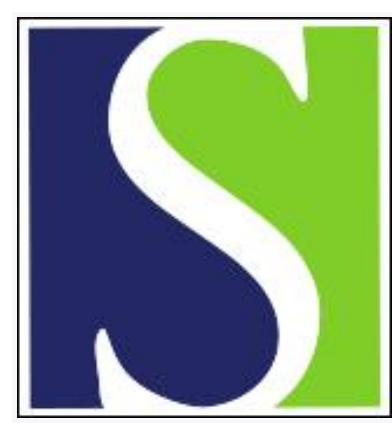

Scand J Work Environ Health 1991;17(4):231-239

https://doi.org/10.5271/sjweh.1708

Issue date: Aug 1991

Renal cell cancer and occupational exposure to chemical agents.

by Partanen T, Heikkila P, Hernberg S, Kauppinen T, Moneta G, Ojajarvi A

Affiliation: Department of Epidemiology and Biostatistics, Institute of Occupational Health, Helsinki, Finland.

This article in PubMed: www.ncbi.nlm.nih.gov/pubmed/1925434

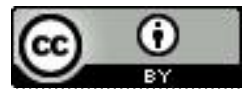




\title{
Renal cell cancer and occupational exposure to chemical agents
}

\author{
by Timo Partanen, MSc, MPh, Pirjo Heikkilä, LPH, Sven Hernberg, MD, \\ Timo Kauppinen, PhD, Giovanni Moneta, PhD, Anneli Ojajärvi, MSc ${ }^{1}$
}

\begin{abstract}
PARTANEN T, HEIKKILÄ P, HERNBERG S, KAUPPINEN T, MONETA G, OJAJÄRVI A. Renal cell cancer and occupational exposure to chemical agents. Scand $J$ Work Environ Health 1991;17:231-9. A case-referent study of occupational risk indicators of renal cell adenocarcinoma was conducted. Each incident case in Finland in 1977-1978 was matched with two population referents. Lifelong job histories were collected and translated into indicators of industry, occupation, and occupational exposures. The analyses of 338 sets of cases and referents revealed elevated risks for a history of employment in whitecollar occupations; the printing industry; the chemical industry; the manufacturing of metal products; mail, telephone, and telegraph services; and iron and metalware work. A decreased risk was observed for male farmers. An elevated risk and an exposure-response relationship were found for gasoline exposure. The excess risk was highest at a latency period of approximately 30 years. The findings support the hypothesis that exposure to some constituent(s) of gasoline increases the incidence of renal adenocarcinoma in humans. Suggestions of elevated risks appeared for exposures to inorganic lead, cadmium, and nonchlorinated solvents.
\end{abstract}

Key terms: cadmium, case-referent study, gasoline, industries, lead, occupations, solvents.

The occupational determinants of renal cancer are poorly understood. Although several epidemiologic studies $(1-23)$ have related specific industries and occupations with the risk of renal cell cancer, no consistent pattern emerges from these studies. Epidemiologic and experimental evidence has brought forth hypotheses on presumed work-related determinants of renal cell cancer. Those of primary concern are various hydrocarbon derivatives (24-26), petrochemicals and gasoline, jet fuel and other products of petroleum refining $(16,27-29)$; gasoline exhaust $(18,30)$; cadmium (31); inorganic lead compounds $(10,32)$; and asbestos $(21,22,33)$.

The objective of this study was to provide further insight into the occupational etiology of renal cell cancer.

\section{Subjects and methods}

The risk of contracting renal cell cancer was studied in relation to industrial categories, occupational titles, and occupational exposures in a case-referent study among Finnish residents ever engaged in worklife either as an employee or as an entrepreneur. All cases, 672 in number, of primary renal adenocarcinoma (code 189,00 of the International Classification of Diseases, seventh revision) newly diagnosed in 1977 and 1978

\footnotetext{
1 Department of Epidemiology and Biostatistics, Institute of Occupational Health, Helsinki, Finland.
}

Reprint requests to: Mr T Partanen, Department of Epidemiology and Biostatistics, Institute of Occupational Health, Topeliuksenkatu 41 a A, SF-00250 Helsinki, Finland. among Finnish residents over the age of 20 years at diagnosis were identified through the Finnish Cancer Registry. Two referents, individually matched to each case on year of birth, gender, and survival status at the time of data collection, were randomly identified, within the constraints of matching, from the Population Register Centre. A questionnaire, with up to two reminders, on job history, smoking, consumption of coffee, and obesity was sent to both the cases and the referents who were alive and to the next-of-kin of the deceased subjects. There was no reference to renal cancer in the questionnaire. The subjects were advised to contact an interviewer by telephone if they felt that it would be more convenient for them. The number of completed forms for the cases or their next-of-kin was 461 (response rate $69 \%$ ); for the referents or their next-of-kin the corresponding number was $915(68 \%)$ (table 1).

After exclusion of the subjects who did not report any history of employment or self-employment (eg, those permanently incapacitated for work and housewives), 408 eligible cases and 819 referents remained (table 1). The number of eligible matched sets of cases and referents was 338,192 cases having one referent and 146 cases having two referents.

The mean age, at diagnosis, of the eligible cases and their referents was 63 (range 26-95) years. The women were older than the men by 2.4 years on the average.

The questionnaire requested information on the different jobs held, time periods of employment, and the identification of employers. This information enabled the reconstruction of the individual occupational histories on an annual basis. The histories were coded, year by year, into industr $\mathrm{i}, \mathrm{s}$ and occupational cate- 
Table 1. Distribution of the identified subjects, respondents, and those ever in worklife among the cases of primary renal cell carcinoma and their referents, by vital status.

\begin{tabular}{|c|c|c|c|c|c|c|}
\hline \multirow{2}{*}{ Vital status } & \multirow{2}{*}{$\begin{array}{l}\text { Number of } \\
\text { identified } \\
\text { subjects }\end{array}$} & \multicolumn{3}{|c|}{ Respondents } & \multirow{2}{*}{$\begin{array}{c}\text { Response } \\
\text { rate }(\%)\end{array}$} & \multirow{2}{*}{$\begin{array}{c}\text { Number } \\
\text { ever } \\
\text { in work } \\
\text { life }\end{array}$} \\
\hline & & $\begin{array}{l}\text { Question- } \\
\text { naire }\end{array}$ & $\begin{array}{l}\text { Tele- } \\
\text { phone }\end{array}$ & All & & \\
\hline \multicolumn{7}{|l|}{ Alive } \\
\hline $\begin{array}{l}\text { Cases } \\
\text { Referents }\end{array}$ & $\begin{array}{l}140 \\
280\end{array}$ & $\begin{array}{r}99 \\
215\end{array}$ & $\begin{array}{l}7 \\
5\end{array}$ & $\begin{array}{l}106 \\
220\end{array}$ & $\begin{array}{l}75.7 \\
78.6\end{array}$ & $\begin{array}{r}98 \\
195\end{array}$ \\
\hline All & 420 & 314 & 12 & 326 & 77.6 & 293 \\
\hline \multicolumn{7}{|l|}{ Deceased } \\
\hline $\begin{array}{l}\text { Cases } \\
\text { Referents }\end{array}$ & $\begin{array}{r}532 \\
1064\end{array}$ & $\begin{array}{l}330 \\
655\end{array}$ & $\begin{array}{l}25 \\
40\end{array}$ & $\begin{array}{l}355 \\
695\end{array}$ & $\begin{array}{l}66.7 \\
65.3\end{array}$ & $\begin{array}{l}310 \\
624\end{array}$ \\
\hline Alt & 1596 & 985 & 65 & 1050 & 65.8 & 934 \\
\hline \multicolumn{7}{|l|}{ All } \\
\hline $\begin{array}{l}\text { Cases } \\
\text { Referents }\end{array}$ & $\begin{array}{r}672 \\
1344\end{array}$ & $\begin{array}{l}429 \\
870\end{array}$ & $\begin{array}{l}32 \\
45\end{array}$ & $\begin{array}{l}461 \\
915\end{array}$ & $\begin{array}{l}68.6 \\
68.1\end{array}$ & $\begin{array}{l}408 \\
819\end{array}$ \\
\hline All & 2016 & 1299 & 77 & 1376 & 68.3 & 1227 \\
\hline
\end{tabular}

Table 2. Definitions a of background, low, and high level of exposure for the different agents. [OEL $=$ occupational exposure limit (36)]

\begin{tabular}{|c|c|c|c|}
\hline \multirow{2}{*}{ Agent } & \multicolumn{3}{|c|}{ Exposure level } \\
\hline & Background & Low & High \\
\hline Asbestos (fibers $/ \mathrm{cm}^{3}$ ) & $<0.1$ & $0.1-1$ & $>1$ \\
\hline Animals & - & $\begin{array}{l}\text { Farmers with } \\
\text { livestock }\end{array}$ & $\begin{array}{l}\text { Butchers, } \\
\text { cattie } \\
\text { tenders }\end{array}$ \\
\hline $\begin{array}{l}\text { Cadmium and } \\
\text { cadmium compounds } \\
\left(\mathrm{mg} / \mathrm{m}^{3}\right)\end{array}$ & $<0.001$ & $0.001-0.01$ & $>0.01$ \\
\hline $\begin{array}{l}\text { Lead and inorganic } \\
\text { lead compounds } \\
\left(\mathrm{mg} / \mathrm{m}^{3}\right)\end{array}$ & $<0.001$ & $0.001-0.05$ & $>0.05$ \\
\hline Oil mist (mg/m³) & $<0.1$ & $0.1-3$ & $>3$ \\
\hline $\begin{array}{l}\text { Nonchlorinated } \\
\text { solvents }\end{array}$ & $<0.02 \times O E L$ & $(0.02-1) \times O E L$ & $>\mathrm{OEL}$ \\
\hline $\begin{array}{l}\text { Gasoline } \\
\text { (ppm benzene) }\end{array}$ & $<0.1$ & $0.1-1$ & $>1$ \\
\hline $\begin{array}{l}\text { Diesel fuel and other } \\
\text { distilled fuel oils }\end{array}$ & & $\begin{array}{l}\text { Operators of } \\
\text { diesel-driven } \\
\text { vehicles }\end{array}$ & $\begin{array}{l}\text { Mechanics } \\
\text { of diesel- } \\
\text { driven } \\
\text { vehicles, } \\
\text { etc }\end{array}$ \\
\hline $\begin{array}{l}\text { Polycyclic aromatic } \\
\text { hydrocarbons } \\
\text { ( } \mathrm{gg}_{\mathrm{g}} \mathrm{m}^{3} \text { benzo[a]pyrene) }\end{array}$ & $<0.01$ & $0.01-1$ & $>1$ \\
\hline
\end{tabular}

a The concentrations given are approximate guideposts rather than precise values.

gories according to the rubrics of the Finnish adaptation (34) of the International Standard Industrial Classification and the Finnish adaptation (35) of the Nordic Classification of Occupations. Summary indicators of the selected industries and occupational categories were then calculated for each subject for the period 1920-1968 (to allow for a latency period for occupational exposures of at least 10 years) as follows: $0=$ no employment in the industry or occupational category during 1920-1968; 1 = one to four years of employment in the industry or occupational category during 1920-1968 (irrespective of the distribution of the years of employment over the period), $2=$ minimum of five years of employment during 1920-1968; * = no data or insufficient data (deleted from the analyses). The coding was done blindly with regard to the casereferent status of the subjects.

The individual occupational histories were then scored by an industrial hygienist (PH) into annual indicators for the years 1920 through 1968 for each of the following occupational exposures: asbestos, exposure to livestock, cadmium and cadmium compounds, lead and inorganic lead compounds, oil mist, nonchlorinated solvents, gasoline, diesel fuel and other distilled fuel oils, and polycyclic aromatic hydrocarbons (PAH). The industrial hygienist was blinded as to the case-referent status of the subjects. The scoring procedure relied on both the knowledge and experience of the industrial hygienist and data obtained from 190 interviews conducted with technical personnel, foremen, occupational health nurses, or workers who had experience with the processes, ventilation, raw materials, and hygienic conditions of the workplaces during the years of interest. Each annual exposure was scored on the following ordinal scale: background level of exposure, low-level exposure, high-level exposure, and exposure level not known. The definitions (table 2) of the three levels of exposure (background, low and high) were applied to the annual data of each subject. The level of exposure was classified as low or high if the levels given in table 2 were considered to exist longer than $30 \%$ of the normal annual worktime. The concentrations defining the different levels of exposure formed approximate guideposts rather than precise figures.

Since vapors of engine fuels are complex mixtures of a substantial number of hydrocarbons and additives, benzene was used as a convenient indicator agent for gasoline. Gasoline exposure was classified as high when the benzene exposure was considered to have exceeded $1 \mathrm{ppm}$ and low in the approximate range of $0.1-1$ 
ppm. Diesel fuels and related mixtures do not volatilize to a degree that is significant for human inhalation exposure except under special conditions, for example, in confined spaces or at high operating temperatures. The exposure to diesel and other distilled fuel oils was considered high when these mixtures were used as cleaning agents or were used continuously in the repair of diesel engines. Low-level exposure referred to the operation of diesel engines.

Care was taken to avoid false positive classifications of industries, occupations, and exposures, as they induce considerable bias in the odds ratio (OR) estimates when the proportion of true positive classifications is low. Uncertain situations were coded as missing values and deleted from the analyses.

For the estimation of the odds ratios for each agent, the annual individual assignments of the different exposures were transformed into summary indicators of the no-yes type as follows: $0=$ background exposure, $1=$ at least five years of high- or low-level exposure before 1968 or less than five years of exposure but at least one year of high-level exposure during 1920$1968,{ }^{*}=$ unknown (deleted from the analyses) or exposure categories between 0 and 1 (deleted to create an effective contrast).

Conditional logistic regression was used throughout the analysis, the case-referent status always being the dependent variable. The incidence density ratios for the different industries, job-title categories, and exposures were estimated as odds ratios, with the respective summary indicators as regressors. The corresponding $95 \%$ confidence intervals $(95 \% \mathrm{CI})$ were calculated on the assumption of a Gaussian distribution of the estimates of the coefficients of the logit model. The analyses were done separately for the men and women, and, in some analyses, for both genders combined. Questionnaire-based indicators of smoking (never/ever), coffee consumption (no/medium/heavy) and obesity (five-point rating scale from lean to obese) were added to most of the models to control for possible nonoccupational confounding by these variables. Missing values ( 16 for smoking, 17 for obesity, and 20 for coffee) were replaced by gender-specific group means for these, and only for these, variables. Coffee consumption was treated as a potential confounder, as heavy coffee drinking may be associated with renal cell cancer $(29,37,38)$.

In addition to the qualitative analyses, exposureresponse relationships for gasoline exposure were examined. Renal cell cancer risk was analyzed in relation to (i) the mean level of exposure (estimate of the time-weighted average in parts per million of benzene in the gasoline vapor, calculated across all the years with higher than background level of exposure in the period 1920-1977), (ii) the total duration of exposure (in years) in the same period, (iii) the cumulative exposure (ppm-years = product of mean level and duration), and (iv) the latency period (1978 minus year of first recorded exposure).

\section{Results}

\section{Nonoccupational confounders}

The odds ratio was $1.3(95 \% \mathrm{CI} 0.9-1.8)$ for smoking (ever), $1.2(95 \% \mathrm{Cl} 0.9-1.7)$ for obesity (slightly overweight or obese), and 1.0 ( $95 \% \mathrm{CI} 0.7-1.4$ ) for coffee consumption (heavy). For women, the odds ratio for heavy coffee consumption was $1.4(95 \% \mathrm{CI}$ $0.7-2.8$ ). While no statistically significantly elevated OR estimates were obtained, control for possible confounding due to these factors was considered prudent.

\section{Industries and occupational categories}

The odds ratios associated with employment or selfemployment for at least five years in selected industries and occupations in the period 1920-1968 are summarized in tables 3 (men) and 4 (women). The selection of the industrial and occupational categories was done on the basis of a minimum of two cases in the industry or occupation. In addition, some industrial and occupational subcategories were not analyzed because we postulated that they did not involve any conceivable determinants of renal cell cancer.

Among industries, a statistically significantly depressed risk was observed for male farmers. Excess risks were observed for both the men and women employed in the printing and publishing industry, for the men employed in chemical and related industries, for the men employed in the manufacturing of metal products, machinery, and equipment, and for both the men and women in mail, telephone and telegraph services. For the mail, telephone and telegraph services, the OR pooled over the two genders was 4.9 (95\% CI 1.3-18.4).

Among occupations, a significant excess risk was associated with the aggregate category of technical artistic, administrative, managerial and clerical occupations for the men but not for the women. A statistically significant deficit occurred for the men in agricultural occupations but not for the women. Elevated OR estimates were associated with men in iron and metalware occupations and with men in graphic work. The latter excess was concentrated in the small subgroup of printers (OR 6.0).

\section{Occupational exposures}

Table 5 shows the OR estimates for the different occupational exposures for the men and women combined, unadjusted for any confounders. Gasoline exposure was significantly associated with the risk of renal cell cancer. The OR estimates for cadmium, lead, and nonchlorinated solvents were elevated, but not statistically significantly so. In the subpopulation of blue-collar occupations (white-collar and farming occupations being excluded), the OR for lead and lead compounds was $5.2(95 \% \mathrm{Cl} 0.5-6.5)$ as compared with 2.9 for the entire data, for nonchlorinated solvents it was 4.5 (95\% CI 0.9-22.2) compared with 
Table 3. Odds ratio (OR) estimates and their $95 \%$ confidence intervals $(95 \% \mathrm{Cl})$ for men in selected industries and occupations. ${ }^{\mathrm{a}}$

Cases
in the
industryl of
occupa-
tion
(N)

\section{Industry}

Agriculture, hunting, forestry, fishing

Agriculture and hunting Forestry and logging

Manufacturing

Food, beverages, tobacco

Textile, wearing apparel

leather

Wood (except furniture)

Paper and pulp;

printing and publishing

Paper and paper products Printing and publishing

Chemicals; chemical, petroleum coal, rubber and plastic

products

Nonmetallic mineral products

(except petroleum and coal)

Metal products, machinery

and equipment

Electricity, gas, water

Construction

Building

Earth improvement:

excavating and foundation

work; construction of highways

streets, airports, etc

Trade, restaurants, hotels

Transport, storage,

communications

Transport and storage

Mail, telephone and

telegraph services

Financing, real estate and

business services

Community, social and

personal services

Social, health care and

related services

\section{Occupation}

Technical, physical science,

social science, humanistic,

artistic work; administrative,

managerial and clerical work

Sales work

Agriculture, forestry, fishing

Transportation

Manufacturing and related work

Iron and metalware work

Machinists; machine and engine repairmen

Woodwork

Graphic work

Printers

Chemical processing

and related work

Stationary engine and

motorpower work

Contrast: $\geq 5$ years/no employment during 1920-1968; linear adjustment for obesity, smoking and coffee consumption, conditional logistic regression.

2.9, for gasoline it was 3.6 (95 \% CI 1.4-9.2) compared with 1.7, and for PAH it was $4.4(95 \% \mathrm{CI}$ 0.4-43.1) compared with 1.1. The higher OR estimates for the blue-collar occupations indicate a nega-
Table 4. Odds ratio (OR) estimates and their $95 \%$ confidence intervals $(95 \% \mathrm{Cl}$ ) for women in selected industries and $\mathrm{oc}$ cupations. ${ }^{a}$

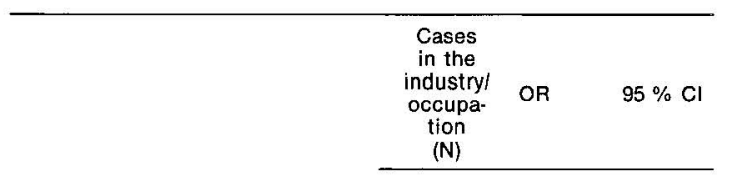

Industry

Agriculture, hunting

forestry,

Agriculture and hunting

$60 \quad 0.96 \quad 0.55-1.66$

Manufacturing

Textiles, leather

Paper and pulp:

printing and publishing

Printing and publishing

Trade, restaurants, hoteis

Transportation, storage,

communications

Mail, telephone and

telegraph services

Community, social and

personal services

Social, health care and

related services

$59 \quad 0.96 \quad 0.56-1.65$

$19 \quad 1.08 \quad 0.54-2.15$

$10 \quad 1.68 \quad 0.66-4.31$

$7 \quad 5.95 \quad 1.21-29.2$

$\begin{array}{lll}5 & 8.01 & 0.92-69.8\end{array}$

$19 \quad 1.29 \quad 0.63-2.66$

$8 \quad 2.75 \quad 0.68-11.1$

$6 \quad 6.58 \quad 0.75-57.4$

$18 \quad 0.83 \quad 0.43-1.64$

$6 \quad 0.80 \quad 0.28-2.34$

Occupation

Technical, physical science,

social science, humanistic,

artistic work; administrative,

managerial and clerical work

Sales work

Agriculture, forestry, fishing

Agricultural and horticultural work, animal husbandry

Manufacturing and

related work

$\begin{array}{lll}10 & 0.86 & 0.34-2.18 \\ 12 & 1.36 & 0.54-3.38 \\ 59 & 1.02 & 0.59-1.76 \\ 47 & 1.07 & 0.51-1.85 \\ 16 & 1.20 & 0.57-2.49\end{array}$

a Contrast: $\geq 5$ years/no employment during $1920-1968$, linear adjustment for obesity, smoking and coffee consumption, conditional logistic regression.

tive confounding in the aggregate data due to social class and agricultural occupation or rural/urban gradient.

As the conditions of exposure might have been different for the men and women, the OR estimates for the different exposures were calculated separately for the two genders. For the men (table 6), the OR estimates adjusted for the nonoccupational confounders were similar to the unadjusted OR estimates for both genders combined (table 5). When the white-collar and farming occupations were excluded, the OR for asbestos was 1.6 (95 \% CI 0.4-6.0) compared with 0.9 for the entire data, for lead and lead compounds it was $5.6(95 \% \mathrm{Cl} 0.6-54.8$ ) compared with 2.8 , for nonchlorinated solvents it was 4.8 (95\% CI 1.0-23.8) compared with 3.5, for gasoline it was 3.9 (95\% CI 1.4-10.6) compared with 1.6, and for PAH it was 5.5 (95 \% CI 0.5-58.9) compared with 1.2.

Among the women, the only exposure with a sufficient number of exposed subjects was the category of animal exposures. The OR, adjusted for confounding by smoking, coffee consumption, and obesity, was 1.3 (95\% CI 0.8-2.2). 
Table 5. Odds ratio (OR) estimates and their $95 \%$ confidence intervals $(95 \% \mathrm{Cl}$ ) for various occupational exposures of the men and women combined. ${ }^{a}$

\begin{tabular}{|c|c|c|c|}
\hline Exposure & $\begin{array}{l}\text { Exposed } \\
\text { cases } \\
\text { (N) }\end{array}$ & OR & $95 \% \mathrm{Cl}$ \\
\hline Asbestos & 15 & 1.00 & $0.49-2.05$ \\
\hline Animals & 58 & 0.93 & $0.63-1.39$ \\
\hline $\begin{array}{l}\text { Cadmium and } \\
\text { cadmium compounds }\end{array}$ & 3 & 4.37 & $0.44-43.0$ \\
\hline $\begin{array}{l}\text { Lead and inorganic } \\
\text { lead compounds }\end{array}$ & 4 & 2.89 & $0.52-16.1$ \\
\hline Oil mist & 10 & 1.10 & $0.47-2.53$ \\
\hline $\begin{array}{l}\text { Nonchlorinated } \\
\text { solvents }\end{array}$ & 9 & 2.89 & $0.86-9.74$ \\
\hline Gasoline & 39 & 1.72 & $1.03-2.87$ \\
\hline $\begin{array}{l}\text { Diesel fuel and other } \\
\text { distilled fuel oils }\end{array}$ & 21 & 1.20 & $0.63-2.27$ \\
\hline $\begin{array}{l}\text { Polycyclic aromatic } \\
\text { hydrocarbons }\end{array}$ & 7 & 1.10 & $0.39-3.09$ \\
\hline
\end{tabular}

a Contrast: at least 5 years of a high or low level of exposure before 1968 or less than 5 years of exposure but at least 1 year of high level of exposure during 1920-1968 versus background exposure, conditional logistic regression.

\section{Gasoline exposure}

The level of gasoline exposure was classified as high (h) for 11 cases ( $28 \%$ of the 39 exposed cases) and two referents ( $6 \%$ of the 36 exposed referents) and as low (l) for the remaining exposed cases and referents. The persons exposed to gasoline had worked as vehicle mechanics $\left(\mathrm{N}_{h}=5\right)$, operators of a relief-printing press $\left(\mathrm{N}_{\mathrm{h}}=3\right)$, a rotogravure pressman cleaning cylinders with gasoline $\left(\mathrm{N}_{\mathrm{h}}=1\right)$, a weigher of containers and trucks in an oil refinery $\left(\mathrm{N}_{\mathrm{h}}=1\right)$, a road tanker driver $\left(\mathrm{N}_{\mathrm{h}}=1\right)$, a service station attendant $\left(\mathrm{N}_{1}=1\right)$, a firefighter $\left(\mathrm{N}_{1}=1\right)$, taxi drivers $\left(\mathrm{N}_{1}=4\right)$, operators of other gasoline-driven vehicles $\left(\mathrm{N}_{1}=22\right)$.

The exposed referents were vehicle mechanics $\left(\mathrm{N}_{\mathrm{h}}=1\right.$ and $\mathrm{N}_{1}=2$ ), a press operator and foreman in a relief-printing shop $\left(\mathrm{N}_{\mathrm{h}}=1\right)$, lumberjacks $\left(\mathrm{N}_{1}=2\right)$, a service station attendant $\left(\mathrm{N}_{1}=1\right)$, taxi drivers $\left(\mathrm{N}_{1}=7\right)$, operators of other gasoline-driven vehicles $\left(\mathrm{N}_{1}=22\right)$.

Three occupational exposures were associated with gasoline exposure in the data and may therefore have confounded the gasoline-renal cancer association [ie, diesel and other distilled fuel oils (positive correlation with gasoline exposure), oil mist (positive correlation with gasoline), and animal exposure (negative correlation with gasoline)]. To control for concomitant exposure to diesel and other distilled fuel oils, we calculated the OR estimates for the persons with exposure to different combinations of gasoline, diesel, and other distilled fuel oils (table 7). Those exposed to gasoline in the absence of exposure to diesel and other distilled fuel oils exhibited the highest OR $(2.1,95 \%$ CI $1.1-$ 4.0), while the OR for those with exposure to diesel and other distilled fuel oils only was 0.7 .
Table 6. Odds ratio (OR) estimates and their $95 \%$ confidence intervals $(95 \% \mathrm{Cl})$ for the occupational exposures of the men. ${ }^{\mathrm{a}}$

\begin{tabular}{lccc}
\hline Exposure & $\begin{array}{c}\text { Exposed } \\
\text { cases } \\
(\mathrm{N})\end{array}$ & OR & $95 \% \mathrm{Cl}$ \\
\hline $\begin{array}{lcc}\text { Asbestos } \\
\text { Animals }\end{array}$ & 14 & 0.94 & $0.45-1.97$ \\
$\begin{array}{l}\text { Cadmium and } \\
\text { cadmium compounds }\end{array}$ & 16 & 0.67 & $0.35-1.31$ \\
$\begin{array}{l}\text { Lead and inorganic } \\
\text { lead compounds }\end{array}$ & $\mathrm{b}$ & $\mathrm{b}$ & $\mathrm{b}$ \\
$\begin{array}{l}\text { Oil mist } \\
\text { Nonchlorinated }\end{array}$ & 4 & 2.77 & $0.49-15.6$ \\
$\begin{array}{l}\text { solvents } \\
\text { Gasoline }\end{array}$ & 10 & 1.07 & $0.46-2.49$ \\
$\begin{array}{l}\text { Diesel fuel and other } \\
\text { distilled fuel oils }\end{array}$ & 9 & 3.46 & $0.91-13.2$ \\
$\begin{array}{l}\text { Polycyclic aromatic } \\
\text { hydrocarbons }\end{array}$ & 39 & 1.63 & $0.97-2.75$ \\
\hline
\end{tabular}

a Contrast: at least 5 years of a high or low level of exposure before 1968 or less than 5 years of exposure but at least 1 year of i,igh level of exposure during 1920-1968 versus background exposure, linear adjustment for obesity, smoking and coffee consumption, conditional logistic regression. b The OR estimates did not converge because of scanty data.

Table 7. Odds ratio (OR) estimates and their $95 \%$ confidence intervals $(95 \% \mathrm{Cl})$ for combinations of the men's exposures to gasoline and diesel and other distilled fuel oils. ${ }^{a}$ b

\begin{tabular}{|c|c|c|c|}
\hline $\begin{array}{l}\text { Exposure } \\
\text { combination }\end{array}$ & $\begin{array}{l}\text { Exposed } \\
\text { cases } \\
\text { (N) }\end{array}$ & OR & $95 \% \mathrm{Cl}$ \\
\hline
\end{tabular}

No gasoline; no diesel

or other distilled

fuel oil

Gasoline only

$\begin{array}{rlc} & 1 & \\ 23 & 2.05 & 1.05-3.98 \\ 6 & 0.68 & 0.23-2.01 \\ 13 & 1.29 & 0.55-3.02\end{array}$

Diesel or other distilled fuel only

Both

13

$0.55-3.02$

a Exposure $=$ at least 5 years of a high or low level of exposure before 1968 or less than 5 years of exposure but at least 1 year of a high level of exposure during 1920-1968.

b Conditional logistic regression.

The simultaneous adjustment for the three exposures associated with gasoline exposure was attained through the recalculation of the OR for gasoline with linear adjustment in the logit model for exposure to diesel and other distilled fuel oil, oil mist, and animals, as well as for smoking, coffee consumption, and obesity. The OR was $1.2(95 \%$ CI $0.6-2.5)$.

Next, the exposure-response gradients for gasoline exposure were scrutinized. The sparseness of the data did not allow for the simultaneous analysis of the mean level, duration, cumulated exposure, and latency period of gasoline exposure. We therefore performed four separate conditional logistic regressions entering one exposure dimension at a time. The distribution of the cases and referents along the four dimensions was unevenly spaced. To increase the stability of the esti- 
Table 8. Fitted odds ratio (OR) estimates and their $95 \%$ confidence intervals $(95 \% \mathrm{Cl})$ for the level, duration, cumulative exposure, and latency period of gasoline exposure of the men. ${ }^{\mathrm{a}}$

\begin{tabular}{|c|c|c|c|}
\hline & $\begin{array}{l}\text { Exposed } \\
\text { cases } \\
\text { (N) }\end{array}$ & OR & $95 \% \mathrm{Cl}$ \\
\hline \multicolumn{4}{|c|}{$\begin{array}{l}\text { Level } \\
\text { (ppm equivalent of benzene) }\end{array}$} \\
\hline $\begin{array}{l}0 \\
0.1-0.19 \\
0.2-0.9 \\
1.0-2.0\end{array}$ & $\begin{array}{r}4 \\
25 \\
10\end{array}$ & $\begin{array}{l}1 \\
0.63 \\
1.55 \\
7.39\end{array}$ & $\begin{array}{c}. \\
0.19-2.12 \\
0.83-2.91 \\
1.58-34.6\end{array}$ \\
\hline \multicolumn{4}{|l|}{$\begin{array}{l}\text { Duration } \\
\text { (years) }\end{array}$} \\
\hline $\begin{array}{l}0 \\
5-11 \\
12-20 \\
21-51\end{array}$ & $\begin{array}{l}\cdot \\
13 \\
13 \\
13\end{array}$ & $\begin{array}{l}1 \\
1.39 \\
2.02 \\
1.58\end{array}$ & $\begin{array}{c}0.61-3.13 \\
0.83-4.90 \\
0.69-3.63\end{array}$ \\
\hline \multicolumn{4}{|c|}{$\begin{array}{l}\text { Cumulative exposure } \\
\text { (ppm-years; benzene } \\
\text { equivalent) }\end{array}$} \\
\hline $\begin{array}{l}0 \\
0.5-1.9 \\
2.0-13 \\
14-102\end{array}$ & $\begin{array}{r}7 \\
23 \\
9\end{array}$ & $\begin{array}{l}1 \\
1.28 \\
1.39 \\
4.34\end{array}$ & $\begin{array}{c}\cdot \\
0.45-3.65 \\
0.75-2.58 \\
1.15-16.4\end{array}$ \\
\hline \multicolumn{4}{|l|}{$\begin{array}{l}\text { Latency } \\
\text { (years) }\end{array}$} \\
\hline $\begin{array}{l}0 \\
17-26 \\
27-33 \\
34-58\end{array}$ & $\begin{array}{l}. \\
10 \\
17 \\
12\end{array}$ & $\begin{array}{l}1 \\
1.23 \\
2.82 \\
1.28\end{array}$ & $\begin{array}{c}0.51-2.96 \\
1.17-6.80 \\
0.56-2.98\end{array}$ \\
\hline
\end{tabular}

a Linear adjustment for obesity, smoking and coffee consumption, conditional logistic regression.

mates, we classified each exposure dimension into four categories containing a reasonably balanced number of subjects. The four categories of each dimension are defined in table 8. Each dimension was treated as a factorized predictor, the unexposed subjects forming the reference category. This procedure allowed for the simultaneous estimation of three OR estimates contrasting the three exposure categories against the unexposed reference category. Obesity, smoking, and coffee consumption were included in each model.

Table 8 shows that the risk of renal cell cancer increased with increasing level of gasoline exposure, as approximated by the benzene-equivalent concentration. The highest level (about 1.0-2.0 ppm of benzene) was associated with a significantly elevated $O R$ of 7.4. No clear trend in the risk was noted for the duration of exposure. The cumulative exposure, reflecting both the level and the duration of exposure, displayed a less steep upward gradient than did its constituent, the level of exposure. The OR for the highest category (benzene equivalent of about $14-102 \mathrm{ppm}$ years) was 4.3. The latency category associated with the highest OR was that of $27-33$ years.

\section{Discussion}

This report addresses the risk of renal cell cancer over industries, occupations, and occupational exposures. No strong ad hoc hypotheses of the chemical exposures as determinants of kidney cancer were set, with the possible exception of exposures to gasoline constituents and lead compounds.

The finding of an increased risk for men in the mixed category of different white-collar occupations is in agreement with results of a number of studies (1-4). The occupational exposures considered in this study were uncommon in the white-collar occupations. There was no clustering of cases into particular subcategories of industry or occupation among the men in whitecollar occupations. Obesity, coffee consumption, or smoking did not explain the elevated risk.

In concordance with Danish (1) and Swedish (2) experience, a significant deficit in renal cancer risk was observed for male farmers.

The excess risk associated with employment in printing and publishing may be explained by gasoline exposure, which was fairly common in this industry, particularly among the men. In addition, exposure to lead and inorganic lead compounds was more frequent for the subjects in this industry than for the rest of the subjects. Both lead and, in particular, gasoline were associated with the risk of renal cell cancer, a finding in agreement with those of animal studies $(27,32)$. A related epidemiologic finding is that of Paganini-Hill et al (20), who reported a significantly increased mortality from kidney cancer among newspaper web pressmen.

An increased risk was associated with the manufacturing of metal products, machinery, and equipment and iron and metalware work among the men. The exposures characterizing these jobs were cadmium, lead, oil mist, solvents, and PAH.

Men in the chemical, petroleum, coal, rubber, and plastics industries had an elevated risk but did not display anything unusual in the frequency of the exposures considered in this study. Closer scrutiny of this heterogeneous group revealed a cluster of three cases out of eight (but none among the referents) with a history of employment in the petroleum industry.

An excess risk was significantly associated with employment in mail, telephone, and telegraph services. No exposure under study was prominent in this industry. The represented occupations comprised postal van drivers, telephone and line installers, and various office jobs.

An elevated OR was observed for cadmium exposure among the men, but it was based on three cases only. The scanty prior evidence is restricted to a single epidemiologic study by Kolonel (31), who reported a significantly elevated OR for occupational exposure to cadmium in a case-referent study.

Lead acetate, lead subacetate, and lead phosphate have induced renal tumors in rats and mice by several routes of administration (32). Selevan and her collaborators (10) have reported elevated kidney cancer mortality for workers in a lead smelter. Two cases of renal cancer associated with heavy exposure to lead have also been reported $(39,40)$. Malcolm \& Barnett 
(41) observed an excess of deaths due to renal diseases among workers exposed to lead in factories producing lead acid batteries. Renal neoplasms were not mentioned by the authors. We found an elevated but statistically nonsignificant $O R$ for exposure to lead and inorganic lead compounds. Of the high-risk industries and occupations, significantly elevated proportions of prior exposure to lead compounds was observed in printing and publishing and iron and metalware work. These findings are somewhat imprecise and do not therefore add much to the existing evidence for the hypothesis of an association between (inorganic) lead and renal cancer. The fact that the gasoline used in Finland, especially in the past, contains tetraethyl lead may be relevant in that gasoline exposure was associated with renal cancer risk. Tetraethyl lead is capable of dermal entrance to the organism, where a part of it is transformed into inorganic lead compounds (42). The amount of lead intake is probably low in the jobs with typical dermal exposure to gasoline, however.

Asbestos exposure has been related to an increased risk of kidney cancer in three epidemiologic studies (21, $22,33)$. Asbestos fibers have been detected in the kidneys of exposed subjects $(43,44)$. Our results fail to substantiate these findings. The false negative rate of exposure assessment was probably highest for asbestos in our study. In addition, it is possible that the latency periods were insufficient, as the peak of asbestos use in Finland occurred around 1970. It would therefore seem that our OR estimate for asbestos was negatively biased. To the contrary, however, occupational titles with a high probability of asbestos exposure (dockyard workers, asbestos insulators, and workers in asbestos quarries, mills and asbestos product manufacturing facilities) were completely absent from our data. Our finding on asbestos is inconclusive.

We observed an elevated OR for nonchlorinated solvents for men. These solvents were constituents of paint and glue formulations (eg, toluene, xylenes, ketones, esters, alcohols, benzene, mineral spirit, and turpentine). The number of persons exposed to chlorinated solvents was too small for statistical analysis. It might be noted that Duh \& Asal (12), Katz \& Jowett (13), and Asal et al (29), who found an elevated kidney cancer risk among laundry and dry-cleaning workers, did not discriminate between petroleum-based and chlorinated solvents as possible risk factors. There was only one case in our data with a history of dry-cleaning work (as an operator).

Gasoline exposure was consistently related to kidney cancer risk in our data. It persisted after control for obesity, smoking, coffee consumption, concomitant diesel fuel exposure, social status, and farming occupations. An exposure-response relation was observed for the level of exposure to gasoline, and a weaker such relation was seen for the cumulative exposure (product of mean level and duration). Duration of exposure alone was not linearly associated with the risk of renal cancer, a finding which might reflect the correlatedness between latency and duration, the latency peak appearing at the intermediate category of around 30 years. The composition of the imported gasoline used in Finland in the late 1940s and early 1950 s is not well known. Tetraethyl lead was used as an anti-knock additive.

Regarding the assessment of some individual exposures to gasoline, the printing press operators (three cases and a referent) used gasoline as a cleaning agent in typographic printing shops. This use was confirmed by nurses and safety personnel of the printing shops concerned. The gasoline exposure (classified as low level) of a firefighter was based on the reporting of the case himself. The exposure of the operators of gasoline-driven vehicles, taxis included, was classified as low level, as their gasoline exposure was considered higher than in the population at large.

Our results suggest that some hydrocarbon constituent(s) or additive(s) of gasoline are conducive to renal cell cancer in humans. The level of exposure is probably important, and the postulated average latency period was about 30 years for the exposure conditions encountered in this study. Epidemiologic studies conducted elsewhere have, however, failed to produce convincing evidence of a relationship between gasoline exposure and renal cell cancer, with the possible exception of aviation gasoline reported by Siemiatycki and his co-workers (28). A suggestion of an exposureresponse relationship between the duration of employment as a gasoline station attendant and the incidence of renal cell cancer has been reported by McLaughlin and his co-workers (23). The implicated dose-response relationship between unleaded gasoline and kidney cancer for the male rat (27) suggests some gasoline hydrocarbon(s) as responsible for the conjectured causal association. However, this finding may also be due to a male rat-specific protein (alpha-2-microglobulin) in the kidney, accumulated in the male rat as a result of exposure to a nephrotoxic hydrocarbon (2,2,4-trimethylpentane), a typical component of gasoline (45-47). The role of lead compounds cannot be ruled out when human exposure is under consideration.

Some remarks on the validity of the study are warranted. The misclassification rates of exposures were probably nondifferential between the cases and the referents because the coder was blinded as to the casereferent status of the subjects. Since the subjects were matched for gender, age, and vital status, the probability of differential misclassification of exposures due to the matching factors (eg, old age) should be low. Every effort was undertaken to avoid, in the scoring of the exposures, false positive misclassifications of exposures, which would have been particularly prone to bias the OR estimates towards unity. High rates of false negative misclassification would however have the same effect, which may be reflected in our result for asbestos exposure. Some nondifferential misclassification may however have been possible by random 
fluctuation when the number of exposed persons was small.

Nonresponse would bias the effect estimates if it were differentially correlated with industries, occupations, and exposures between the cases and referents. This possibility could not be directly checked. We cannot however envisage any reason why the referents exposed, for example, to gasoline would tend to refrain from replying, as compared with the cases. Insofar as nonresponse and the accuracy of work histories are dependent on age, gender, and the data source (self or next-of-kin), the matching that was performed should preclude information bias from these sources. The exclusions of subjects due to incomplete case-referent sets in the conditional analyses were in all likelihood randomly distributed between the cases and referents in occupational categories and exposures. We therefore believe there was no serious bias introduced by these exclusions. The exclusion of all subjects with no reported occupational history was a deliberate restriction of the source population, as those without such a history were noninformative in the study base, which was designed to address occupational exposures.

In conclusion, the most important finding of this study is the qualitative and quantitative evidence contributing credence to the hypothesis that exposure to some constituent(s), hydrocarbons, or additives of gasoline increases the risk of renal adenocarcinoma in humans. Our data do not allow for further chemical specification of this hypothesis.

\section{Acknowledgments}

We acknowledge the contribution of the following colleagues to the study: the staff of the Finnish Cancer Registry, Dr H Koskinen, Dr K Kurppa, Ms R Riala, Dr A Tossavainen, and Ms R Vesanto-Paavola of the Finnish Institute of Occupational Health. Dr A-L Backman prepared the study protocol and initiated the study. Dr J Siemiatycki, Université du Québec, is especially thanked for his expert comments on the manuscript and the data analysis, and Dr J McLaughlin, National Cancer Institute, Bethesda, Maryland, for his constructive criticism of the manuscript. The study was supported by a grant from the Finnish Work Environment Fund.

\section{References}

1. Olsen JH, Jensen OM. Occupation and cancer in Denmark: an analysis of 93810 cases, 1970-1979. Scand J Work Environ Health 1987;13(suppl 1):91 p.

2. McLaughlin JK, Malker HSR, Stone BJ, et al. Occupational risks for renal cancer. $\mathrm{Br}$ J Ind Med 1987;44: 119-23.

3. Williams RR, Stegens NL, Goldsmith JR. Associations of cancer site and type with occupation and industry from the third National Cancer Survey Interview. J Natl Cancer Inst 1977;59:1147-85.

4. Magnani C, Coggon D, Osmond C, Acheson ED. Oc- cupation and five cancers: a case-control study using death certificates. $\mathrm{Br} \mathrm{J}$ Ind Med 1987;44:769-76.

5. Miller BA, Blair A, McCann M. Mortality patterns among professional artists: a preliminary report. J Environ Pathol Toxicol Oncol 1985;6:303-13.

6. Walrath J, Fraumeni JF. Mortality patterns among embalmers. Int $J$ Cancer 1983;31:407-11.

7. Bross IDJ, Viadana E, Houten L. Occupational cancer in men exposed to dust and other environmental hazards. Arch Environ Health 1978;33:300-7.

8. Redmond CK, Ciocco A, Lloyd JW, Rush HW. Longterm mortality study of steelworkers: VI. mortality from malignant neoplasms among coke oven workers. J Occup Med 1972;14:621-9.

9. Redmond CK, Strobino BR, Cypess RH. Cancer experience among coke by-product workers. Ann NY Acad Sci 1976;271:102-15.

10. Selevan SSG, Landrigan PJ, Stern FB, Jones JH. Mortality of lead smelter workers. Am J Epidemiol 1985; 122:673-83.

11. Edling C, Granstam S. Causes of death among lumberjacks. J Occup Med 1980;22:403-6.

12. Duh RW, Asal NR. Mortality among laundry and dry cleaning workers in Oklahoma. Am J Public Health 1984;74:1278-80.

13. Katz RM, Jowett D. Female laundry and dry cleaning workers in Wisconsin: a mortality analysis. Am J Public Health 1981;71:305-7.

14. Bond GG, Reeve GR, Ott MG, Waxweiler RJ. Mortality among a sample of chemical company employees. Am J Ind Med 1985;7:109-21.

15. Hanis NM, Shallenberger LG, Donaleski DL, Sales EA. A retrospective mortality study of workers in three major US refineries and chemical plants: part II. internal comparisons by geographic site, occupation, and smoking history. J Occup Med 1985;27:361-9.

16. Thomas TL, Decoufle P, Moure-Eraso R. Mortality among workers employed in petroleum refining and petrochemical plants. J Occup Med 1980;22:97-103.

17. Bond GG, Shellenberger RJ, Flores GH, Cook RR, Fishbeck WA. A case-control study of renal cancer mortality at a Texas chemical plant. Am J Ind Med 1985;7: 123-39.

18. Brownson RC. A case-control study of renal cell carcinoma in relation to occupation, smoking, and alcohol consumption. Arch Environ Health 1988;43:238-41.

19. Thomas TL, Decoufle P. Mortality among workers employed in the pharmaceutical industry: a preliminary investigation. J Occup Med 1979;21:619-23.

20. Paganini-Hill A, Glazer E, Henderson BE, Ross RK. Cause-specific mortality among newspaper web pressmen. J Occup Med 1980;22:542-4.

21. Enterline PE, Hartley J, Henderson V. Asbestos and cancer: a cohort followed up to death. $\mathrm{Br} \mathrm{J}$ Ind Med 1987; $44: 396-401$

22. Selikoff IJ, Hammond EC, Seidman H. Mortality experience of insulation workers in the United States and Canada, 1943-1976. Ann NY Acad Sci 1979;330: $91-116$

23. McLaughlin J, Blot WJ, Mehl ES, Stewart PA, Venable FS, Fraumeni JF. Petroleum-related employment and renal cell cancer. J Occup Med 1985;27:672-4.

24. Matthews JJ, Walpole AL. Tumours of the liver and kidney induced in Wistar rats with 4'-fluoro-4-aminodiphenyl. Br J Cancer 1952;12:234-41.

25. Maltoni $C$. Recent findings on the carcinogenicity of chlorinated olefins. Environ Health Perspect 1977;21: $1-5$.

26. Kadamani S, Asal NR, Nelson RY. Occupational hydrocarbon exposure and risk of renal cell carcinoma. Am J Ind Med 1989;15:131-41.

27. MacFarland HN, Ulrich CE, Holdsworth CE, Kitchen DN, Halliwell WH, Blum SC. A chronic inhalation study 
with unleaded gasoline vapor. J Am Coll Toxicol 1984; 3:231-47.

28. Siemiatycki J, Dewar R, Nadon L, et al. Associations between several sites of cancer and twelve petroleumderived liquids: results from a case-referent study in Montreal. Scand J Work Environ Health 1987;13: 493-504.

29. Asal NR, Geyer JR, Risser DR, et al. Risk factors of renal cell carcinoma: II. medical history, occupation, multivariate analysis, and conclusions. Cancer Det Prev 1988;13:263-79.

30. Siemiatycki J, Gerin M, Stewart P, et al. Associations between several sites of cancer and ten types of exhaust and combustion products: results from a case-referent study in Montreal. Scand J Work Environ Health 1988; 14:79-90.

31. Kolonel LN. Association of cadmium with renal cancer. Cancer 1976;37:1782-7.

32. International Agency for Research on Cancer (IARC). Overall evaluations of carcinogenicity: an updating of IARC monographs volumes 1 to 42. Lyon: IARC, 1987: 230-2. (IARC monographs on the evaluation of carcinogenic risk to humans; suppl 7.)

33. Maclure M. Asbestos and renal adenocarcinoma: a casecontrol study. Environ Res 1987;42:353-61.

34. Central Statistical Office of Finland. Toimialaluokitus (TOL) 1979 [Standard industrial classification (SIC) 1979]. Helsinki: Central Statistical Office of Finland, 1979.

35. Central Statistical Office of Finland. Asunto- ja elinkeinotutkimuksen ammattiluokitus [Occupational classification of the dwelling and livelihood survey]. Helsinki: Central Statistical Office of Finland, 1975.

36. American Conference of Governmental Industrial Hygienists (ACGIH). Threshold values and biological exposure indices for 1987-88. Cincinnati, OH: ACGIH, 1987.

37. Higginson J, Muir C, Buffler PA. The epidemiology of renal carcinoma in humans with a note on the effect of exposure to gasoline. Adv Mod Environ Toxicol 1984;
$7: 203-26$.

38. Yu MC, Mack TM, Hanisch R, Cicioni C, Henderson BE. Cigarette smoking, obesity, diuretic use, and coffee consumption as risk factors for renal cell carcinoma. J Natl Cancer Inst 1986;77:351-6.

39. Baker EL, Goyer RA, Fowler BA, et al. Occupational lead exposure, nephropathy, and renal cancer. Am J Ind Med 1980;1:139-48.

40. Lilis R. Long-term occupational lead exposure, chronic nephropathy, and renal cancer: a case report. Am J Ind Med 1981;2:293-7.

41. Malcolm D, Barnett HAR. A mortality study of lead workers 1925-76. Br J Ind Med 1982;39:404-10.

42. Tsuchiya K. Lead. In: Friberg L, Nordberg GF, Vouk VB, ed. Handbook on the toxicology of metals; vol II. 2nd ed. Amsterdam: Elsevier Science Publishers, 1986: 341-2.

43. Auerbach O, Conston AS, Garfinkel L, et al. Presence of asbestos bodies in organs other than the lung. Chest 1980;77:133-7.

44. Huang J, Hisanaga N, Sakai K, et al. Asbestos fibers in human pulmonary and extrapulmonary tissues. Am J Ind Med 1988;14:331-9.

45. Olson MJ, Garg BD, Murty CVR, Roy AK. Accumulation of $\alpha_{24}$-globulin in the renal proximal tubules of male rats exposed to unleaded gasoline. Toxicol Applied Pharmacol 1987;90:43-51.

46. Charbonneau M, Lock EA, Strasser J, et al. 2,2,4-Trimethylpentane-induced nephrotoxicity: I. metabolic disposition of TMP in male and female Fischer 344 rats. Toxicol Applied Pharmacol 1987;91:171-81.

47. Lock EA, Charbonneau M, Strasser J, et al. 2,2,4-Trimethylpentane-induced nephrotoxicity: II. the reversible binding of a TMP metabolite to a renal protein fraction containing $\alpha_{2 u}$-globulin. Toxicol Applied Pharmacol 1987;91:182-92.

Received for publication: 5 October 1990 